\title{
IMPROVEMENT OF SCHISTOSOMAL PORTAL HYPERTENSIVE COLOPATHY AFTER SURGICAL TREATMENT
}

\author{
Maria Angelina Carvalho MIRANDA', Álvaro Antônio Bandeira FERRAZ1', \\ Ana Lúcia Coutinho DOMINGUES², Renata Carvalho Miranda CHAVES², \\ Norma JUCÁ ${ }^{3}$ and Diógenes Luiz da MOTA ${ }^{4}$
}

\begin{abstract}
Context - Data on vascular alterations in patients with hepatosplenic schistosomiasis and portal hypertensive colopathy and changes in these after surgery to decrease portal hypertension are limited. Objective - The purpose of this study was to analyse the alterations of portal hypertensive colopathy previously and 6-12 months after splenectomy and gastric devascularization. Methods - Twelve patients with hepatosplenic schistosomiasis who also had upper gastrointestinal bleeding were studied prospectively. Their endoscopic findings before and 6-12 months after the surgery were analysed. In addition, mucosal biopsies from ascending colon, sigmoid colon and rectum at these time points were subjected to histological and histomorphometric assessment. It was used a control group due to lack of normal pattern of the histomorphometric measures of vessels in individuals without portal hypertension. The critical level of significance adopted in all tests was of a maximum probability error of 5\%. Results - Surgery did not lead to significant improvement in histological and endoscopic findings. However, on histomorphometry, there was a significant decrease in the area, diameter and thickness of the vessels in mucosa at all colonic sites. Conclusion - Surgery for decompression of schistosomal portal hypertension has a beneficial effect on the associated colopathy, being best indicated in patients with gastrointestinal bleeding and esophageal varices.
\end{abstract}

HEADINGS - Hypertension, portal. Schistosomiasis mansoni. Colonic diseases. Microvascular descompression surgery.

\section{INTRODUCTION}

Schistosomal portal hypertensive colopathy (PHC) is a frequent complication of chronic liver disease. It may cause lower gastrointestinal bleeding or unidentified chronic anemia in patients with severe portal hypertension ${ }^{(4,11,14)}$. Splenectomy and gastric devascularization, one of the recommended surgical treatments for gastrointestinal bleeding in patients with hepatosplenic schistosomiasis, reduces portal pressure by around $30 \%$, as also the blood flow to the territory of the esophageal varices while preserving liver function ${ }^{(3,5,6,12,16)}$. The effect of such surgery on PHC is unclear. In one study, adolescents with hepatosplenic schistosomiasis and PHC showed vascular alterations at colonoscopy after they had undergone surgical treatment for decompression of the portal vein $^{(10)}$. There are no follow up data on the behavior of PHC after portal decompressive surgery in adult patients. The management of PHC in cirrhotic patients remain undefined. Endoscopics interventions as argon plasma coagulation, shunting procedures and surgical techniques have been described ${ }^{(7,11)}$. The aim of the present study was to assess vascular alterations of PHC using endoscopy, histology and histomorphometry before and after splenectomy and gastric devascularization in hepatosplenic patients due to schistosomiasis mansoni.

\section{METHODS}

This study included 12 patients with hepatosplenic schistosomiasis, portal hypertension and a past history of gastrointestinal bleeding who had undergone colonoscopy and biopsies of the rectal, sigmoid colon and ascending colon mucosa, for histological and histomorphometric analysis before surgical treatment for portal hypertension and 6-12 months postoperatively. These patients had undergone splenectomy, ligature of the left gastric vein and devascularization of the greater gastric curvature. They had attended the schistosomiasis out-patient clinic at the Clinical Hospital, Federal University of Pernambuco, Recife, PE, Brazil, between September 2nd 2003 and September 1st 2005.

Declared conflict of interests of all authors: none.

Department of Gastrointestinal Surgery, Universidade Federal de Pernambuco (UFPE): ${ }^{2}$ Department of Gastroenterology, UFPE, Recife, PE; ${ }^{3}$ Postgraduate in Gastroenterology, Universidade de São Paulo, São Paulo, SP. ${ }^{3}$ Department of Anatomical Pathology, UFPE. 4 Department of Clinical Pathology, UFPE, Recife, PE, Brazil. Correspondence: Dr. Maria Angelina Carvalho Miranda - Av. Boa Viagem, 2900/801 - 51020-000. Recife, PE, Brazil. E-mail: drangelinamiranda@hotmail.com 
A group of 12 subjects with normal colonoscopy and colonic histology were studied as a control group to obtain normal values for various histomorphometric parameters.

Both patients and control subjects were excluded if they reported drinking more than $160 \mathrm{~g} /$ week of alcohol, had been diagnosed with cirrhosis of the liver, tested positive for anti-HCV or anti-HBc, had thrombosis of the portal, splenic or superior mesenteric veins, abdominal aortic stenosis, intestinal inflammatory disease or had undergone abdominal surgery (ileostomy or colostomy).

The study protocol was approved by the Research Ethics Committee of the authors' institution and all patients and control subjects signed an informed consent.

\section{Techniques and procedures}

All patients underwent abdominal ultrasound scan on an Aloka SSD500 machine with a $3.5 \mathrm{MHz}$ convex transducer, using the Cairo Classification in accordance with the WHO protocol $^{(20,21)}$. Pre-operative ultrasound scans identified moderate or severe periportal fibrosis in all cases. Eleven patients had increased portal vein diameter, mean increase of $1.4 \mathrm{~cm}$ (range: $1.2-1.7 \mathrm{~cm} /$ normal value: up to $1.2 \mathrm{~cm}$ ) and all patients presented increased diameter of the splenic vein, mean increase of $1.2 \mathrm{~cm}$ (range: $1.0-1.5 \mathrm{~cm} /$ normal value: up to $0.9 \mathrm{~cm}$ ), confirming the clinical and laboratorial diagnosis of portal hypertension.

Colonoscopy was done after bowel preparation with $10 \%$ mannitol and intravenous sedation with meperidine and midazolam, and under monitoring with pulse oximetry. It was done using a conventional resolution videocolonoscope (Olympus CF-140, Tokyo, Japan.) Colonic mucosal vascular lesions at endoscopy were classified according to the criteria of Tam et al. ${ }^{(18)}$, as follows: erythema (diffuse hyperemic mucosa), telangiectasia (tortuosity and engorgement of small vessels), angiodysplasia (coiled vessels measuring about 1 $\mathrm{cm}$ ), and red spots (hyperemic focus in the mucosa). Rectal varices were evaluated according to the criteria laid down by The Japanese Research Society ${ }^{(19)}$, i.e. tortuous or bluish saccular dilation of the rectal veins above the dentate line (grade 1: up to $3 \mathrm{~mm}$ in diameter, grade 2: 3-6 mm, grade 3: $>6 \mathrm{~mm}$ ). The colopathy was classified into three levels as per the criteria described by Miranda et al. ${ }^{(14)}$, i.e. as degree I (erythema and telangiectasias), II (erythema, telangiectasias and angiodisplasia) or III (erythemas, telangiectasias, angiodysplasias, red spots and rectal varices). Photographs were taken and endoscopic biopsies of the colonic lesions were performed from ascending colon, sigmoid colon and rectum.

Histological evaluation of PHC was based on the studies of Bini et al. ${ }^{(2)}$ and Geboes et al. ${ }^{(8)}$, and the presence of Schistosoma mansoni eggs, granulomas, inflammatory infiltration, edema, hyperemia, vascular dilatation and the proliferation of the blood vessels were looked for. The histological sections were stained with Masson's trichrome ${ }^{(13)}$ and used for histomorphometry in a semi-automatic microscope (Axiolab; Carl Zeiss, Oberkochen, Germany) equipped with an image-capture card and the Image-Lab software (Softium, São Paulo, SP, Brazil). Various measurement for blood vessels followed the criteria of Misra et al. ${ }^{(15)}$.

\section{Statistical analysis}

Quantitative measurements obtained before and after surgery were summarized as median (range). The categorical variables were compared using McNemar test, applied to $2 \times 2$ contigency tables, or Stuart-Maxwell test, to tables with more than two rows/columns. The quantitative variables were compared using the Wilcoxon test. The maximum probability of error was set at $5 \%(P<0.05)$. The tests were carried out using Stata 9.2 SE.

\section{RESULTS}

At endoscopy, 3 (25\%) patients had degree II colopathy and $9(75 \%)$ had degree III colopathy before surgical treatment. After surgery, $4(33 \%)$ patients had degree II and 8 $(67 \%)$ patients had degree III colopathy.

On pre-operative histopathological evaluation of the colonic mucosa, mild and moderate mononuclear inflammatory infiltration was observed in $10(83.3 \%)$ and $1(8.3 \%)$ of cases, respectively. In addition, mild hyperemia was noted in $9(75 \%)$ cases, and mild and moderate capillary ectasia were observed in $5(41.7 \%)$ and $1(8.3 \%)$ cases, respectively. In post-operative histopathology, mild mononuclear inflammatory infiltration was observed in $7(58.3 \%)$ cases and moderate mononuclear infiltration in $3(25 \%)$ cases; in addition, mild hyperemia was found in $6(50 \%)$ cases and mild capillary ectasia in $1(8.3 \%)$ case (Table 1).

TABLE 1. Pre- and post-operative histological findings in blood vessels in colonic mucosal biopsies from patients with hepatosplenic schistosomiasis

\begin{tabular}{|c|c|c|c|c|c|c|c|c|c|c|c|c|c|c|c|c|}
\hline & \multicolumn{4}{|c|}{$\begin{array}{l}\text { Mononuclear Inflammatory } \\
\text { Infiltration }\end{array}$} & \multicolumn{4}{|c|}{ Hyperemia } & \multicolumn{4}{|c|}{ Edema } & \multicolumn{4}{|c|}{ Capillary ectasia } \\
\hline & \multicolumn{2}{|c|}{ Pre-op } & \multicolumn{2}{|c|}{ Post-op } & \multicolumn{2}{|c|}{ Pre-op } & \multicolumn{2}{|c|}{ Post-op } & \multicolumn{2}{|c|}{ Pre-op } & \multicolumn{2}{|c|}{ Post-op } & \multicolumn{2}{|c|}{ Pre-op } & \multicolumn{2}{|c|}{ Post-op } \\
\hline & $\mathrm{n}$ & $\%$ & $\mathrm{n}$ & $\%$ & $\mathrm{n}$ & $\%$ & $\mathrm{n}$ & $\%$ & $\mathrm{n}$ & $\%$ & $\mathrm{n}$ & $\%$ & $\mathrm{n}$ & $\%$ & $\mathrm{n}$ & $\%$ \\
\hline Normal & 1 & 8.3 & 2 & 16.6 & 3 & 25 & 6 & 50 & 4 & 33.0 & 7 & 58.3 & 6 & 50 & 11 & 91.6 \\
\hline Mild & 10 & 83.3 & 7 & 58.3 & 9 & 75 & 6 & 50 & 7 & 58.3 & 5 & 41.6 & 5 & 41.6 & 1 & 8.3 \\
\hline Moderate & 1 & 8.3 & 3 & 25 & & & & & 1 & 8.3 & & 0 & 1 & 8.3 & & 0 \\
\hline$P$-value & \multicolumn{4}{|c|}{$0.223^{\mathrm{a}}$} & \multicolumn{4}{|c|}{$0.375^{\mathrm{b}}$} & \multicolumn{4}{|c|}{$0.508^{c}$} & \multicolumn{4}{|c|}{$0.063^{\mathrm{d}}$} \\
\hline
\end{tabular}

a: Stuart-Maxwell test; b,c,d: McNemar test 
None of the 12 control subjects showed any mucosal abnormalities at colonoscopy or any signs of inflammatory process or vascular alterations at histopathologic examination of the rectal, sigmoid and ascending colon mucosa. On statistical analysis, there was no significant difference in the endoscopic and histological change before and after surgery.

On histomorphometric evaluation, the maximum and minimum diameters and wall thickness of blood vessels in the rectum, sigmoid and ascending vessel walls before surgery (Figure 1, Table 2 ) were significantly higher in patients than in the controls $(P<0.05)$. All the measurements showed a decline after the surgery than before it $(P<0.05$; Table 2$)$.

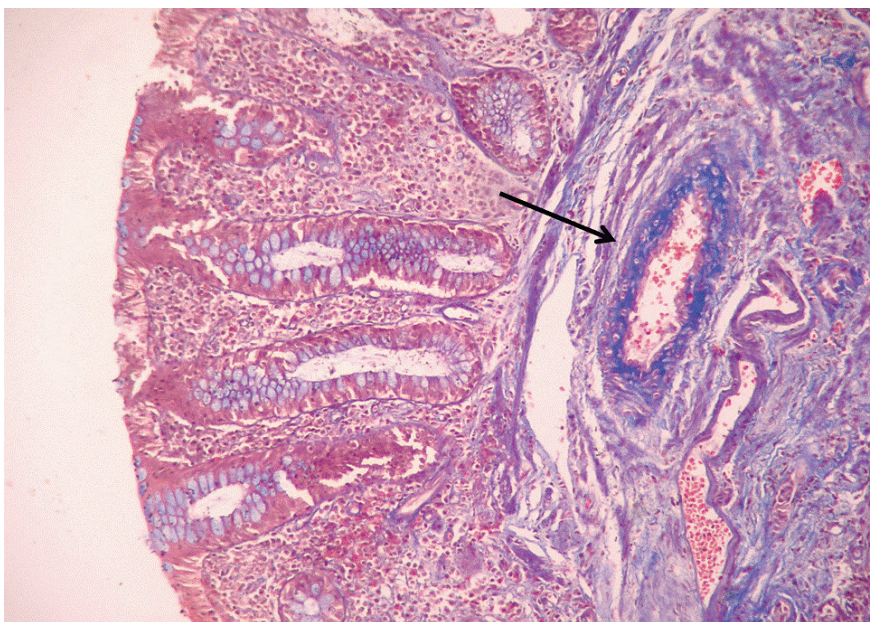

FIGURE 1. Histomorphometry: colonic mucosa displays the lamina propria with vessel walls (TM approx. 400x).

\section{DISCUSSION}

The lesions observed in PHC of cirrhotic patients are similar to schistossomotics. They both have a colitis-like lesion with vascular abnormalities and this lesions are more severe in portal hypertension ${ }^{(4,9,14)}$. In our study, all patients had previous digestive bleeding and presented mild to moderate mononuclear inflammatory infiltration, hyperemia and capillary ectasia in histopathological evaluation. We showed a decrease of PHC intensity by endoscopy and histopathological assessment. However, due to the small number of patients in this study, the differences were not statistically significant. In this series, the histomorphometry demonstrated a significant reduction in the vessel areas, diameters and thickness in the mucous membranes of the rectum, sigmoid colon and ascending colon. We observed a greater reduction in vessel diameter than in the thickness and area. This positive response is due to the influence of portal pressure reduction in vessel diameter. On the other hand, the vessel thickness depends on tissue collagen deposition, which is a more persistent alteration and it takes more time to decrease. Currently, the endoscopic treatment for portal hypertension gastrointestinal bleeding due to esophageal varices is endoscopic band ligation ${ }^{(1,17)}$. However, it was showed that the PHC may be more frequent in patients with previous endoscopic variceal treatment ${ }^{(7)}$. Therefore, it is important to perform a colonoscopy in hepatosplenic schistosomotic patients with GI bleeding and esophageal varices before choosing the most appropriate treatment. If they have PHC, surgical procedure is indicated because this treatment can reduce these vascular lesions.

TABLE 2. Pre- and post-operative histomorphometric findings in blood vessels in colonic mucosal biopsies from patients with hepatosplenic schistosomiasis

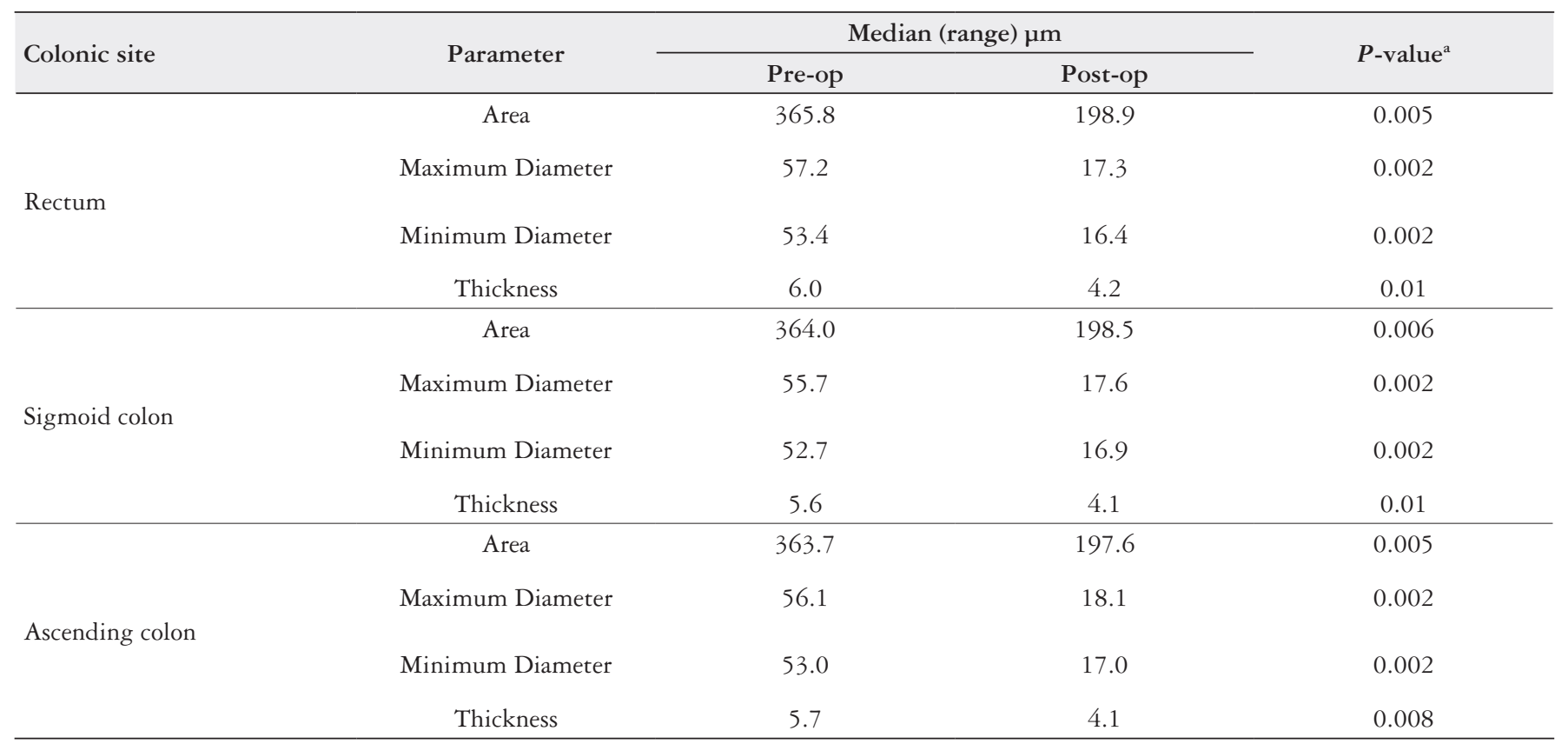

a: Wilcoxon test 


\section{ACNOWLEDGMENTS}

We thank Mr. Jose Natal Figueroa the statistical advice, staff over the public health and clinical laboratory who helped in data collection. No external financial support was received for this study.

Miranda MAC, Ferraz AAB, Domingues ALC, Chaves RCM, Jucá N, Mota DL. Melhora da colopatia hipertensiva portal esquistossomótica após tratamento cirúrgico. Arq Gastroenterol. 2013,50(2):153-6.

RESUMO - Contexto - Dados em relação às alterações vasculares em pacientes com esquistossomose hepatoesplênica e colopatia hipertensiva portal e suas modificações após cirurgia para atenuação da hipertensão portal são restritos. Objetivo - Analisar as alterações da colopatia hipertensiva portal antes e seis a 12 meses após a esplenectomia e desvascularização gástrica. Métodos - Foram estudados prospectivamente 12 pacientes com esquistossomose hepatoesplênica e antecedente de hemorragia digestiva alta. Os achados colonoscópicos antes e após 6 a 12 meses após a cirurgia foram analisados. Nesses períodos, biopsias da mucosa do cólon ascendente, sigmóide e reto foram encaminhadas para análise histológica e histomorfométrica. Foi utilizado um grupo controle pela falta de padrão de normalidade das medidas histomorfométricas das vênulas do cólon e reto em indivíduos sem hipertensão portal. O nível de significância crítica adotado em todos os testes foi de probabilidade máxima de erro de $5 \%$. Resultados - Não foram encontradas diferenças significantes na intensidade das alterações endoscópicas e histológicas nos vasos da mucosa do cólon e reto após a cirurgia. Entretanto, houve decréscimo estatisticamente significante nas áreas, diâmetros e espessuras dos vasos estudados através da histomorfometria. Conclusão - Cirurgia para descompressão da hipertensão portal esquistossomótica tem efeito benéfico na colopatia associada, sendo bem indicada nos pacientes com hemorragia digestive alta e varizes esofágicas.

DESCRITORES - Hipertensão portal. Esquistossomose mansoni. Doenças do cólon. Cirurgia de descompressão micro vascular.

\section{REFERENCES}

1. Bari K, Gaecia-Tsao G. Treatment of portal hypertension. World J Gastroenterol. 2012;18:1166-75.

2. Bini EJ, Lascarides CE, Micale PL, Weinshel EH. Mucosal abnormalities of the colon in patients with portal hypertension: an endoscopic study. Gastrointest Endosc. 2000;52:511-16.

3. de Cleva R, Herman P, D'Albuquerque LAC, Pugliese V, Santarem OL, Saad WA. Pre and postoperative systemic hemodynamic evaluation in patients subjected to esophagogastric devascularization plus splenectomy and distal splenorenal shunt: a comparative study in schistosomal portal hypertension. World J Gastroenterol. 2007;13:5471-5.

4. Diaz-Sanches A, Nuñez-Martinez O, Gonzalez-Asanza C, Matilla A, Merino B, Rincon D, Beceiro I, Catalina MV, Salcedo M, Bañares R, Clemente G. Portal hypertensive colopathy is associated with portal hypertension severity in cirrhotic patients. World J Gastroenterol. 2009;15:4781-7.

5. Ferraz AA, Albuquerque PC, Lopes EP, de Araújo JG Jr, Carvalho AH, Ferraz EM. The influence of periportal (pipestem) fibrosis on long term results of surgical treatment for schistosomotic portal hypertension. Arq Gastroenterol. 2003;40:4-10.

6. Ferraz AA, Bacelar TS, Silveira MJ, Coelho AR, Câmara Neto RD, de Araújo Júnior JG, Ferraz EM. Surgical Treatment of Schistosomal Portal Hypertension. Int Surg. 2001;86:1-8.

7. Gad YZ, Zeid AA. Portal hypertensive colopathy and haematochezia in cirrhotic patients: na endoscopic study. Arab J Gastroenterol. 2011;12:184-8.

8. Geboes K, el-Deeb G, el-Haddad S, Amer G, el-Zayadi AR. Vascular alterations of the colonic mucosa in schistosomiasis and portal colopathy. Hepatogastroenterology. 1995;42:343-47.

9. Jeong IB, Lee TH, Lim SM, Ryu KH, Kim SM, Im EH, Huh KC, Choi YW, Kang YW. Endoscopic findings and clinical significance of portal hypertensive colopathy. Korean J Gastroenterol. 2011;58:332-7.
10. Justo CR, Brandt CT, Lucena MT, Jales M. Effect of splenectomy and ligature of the left gastric vein on portal hypertensive colopathy in carriers of surgical hepatosplenic schistosomiasis mansoni. Acta Cir Bras. 2005;20:9-14.

11. Kalafateli M, Triantos CK, Nikolopoulou V, Burroughs A. Dig Dis Sci 2012;57:2743-54

12. Kelner S. Critical evaluation of schistosomotic portal hypertension surgery. Mem. Inst. Oswaldo Cruz. 1992;87:357-68.

13. McElroy DA. Tejido Conectivo. In: Prophet EB, Mills B, Arrington JB e Sobin LH. Métodos Histotecnológicos. Washington, DC: Registro de Patología de los Estados Unidos da América (ARP), 1992; pp 135-36.

14. Miranda MA, Domingues AL, Dias HS, Miranda RC, Jucá NT, Albuquerque MF, Cordeiro FT. Hypertensive portal colopathy in schistosomiasis mansoni proposal for a classification. Mem Inst Oswaldo Cruz. 2004;99: 67-71.

15. Misra V, Misra SP, Dwivedi M, Gupta SC. Histomorphometric study of portal hypertensive enteropath. Am J Clin Pathol. 1997;108:652-7.

16. Petroianu A. Surgical treatment of portal hypertension in schistosomiasis mansoni Rev. Soc. Bras. Med Trop. 2003;36:235-65.

17. Poza Cordon J, Froilan Torres C, Burgos García A, Gea Rodriguez F, Suárez de Parga JM. Endoscopic management of esophagel varices. World J Gastrointest Endosc. 2012;4:312-22.

18. Tam TN, Ng WW, Lee SD. Colonic mucosal changes in patients with liver cirrhosis. Gastrointest Endosc 1995;42:408-12.

19. The general rules for recording endoscopic findings on esophageal varices. Japanese J Surg 1980;10:84-7.

20. The use of diagnostic ultrasound in schistosomiasis- -attempts at standardization of methodology. Cairo Working Group. Acta Trop. 1992;51:45-63.

21. WHO. The Control of Schistosomiasis. Second report of the WHO expert committee. Proposal for a practical guide to the standardized use of ultrasound in the assessment of pathological changes. Meeting on ultrasonography in schistosomiais. Cairo, Egypt: 1-4 October, 1990. Cairo, Egypt. Technical report series, 830, 1993. 